\title{
Memores Acti Prudentes Future!
}

\author{
Atul P Kulkarni ${ }^{1}$, Deepak Govil ${ }^{2}$ \\ Indian Journal of Critical Care Medicine (2022): 10.5005/jp-journals-10071-24101
}

The first scientific journal (not exclusively medical) to be published was the French journal, Le Journal des Sçavans, which appeared in January 1665 . Though the Royal Society of London, an academy of sciences, became the first body dedicated to describing scientific experiments, began working in 1660, its scientific publication, the first English journal, Philosophical Transactions, was started as its regular publication in April 1665. Acta Medica et Philosophica Hafniensia was probably the first dedicated medical journal, which first appeared in 1673. This was edited by Thomas Bartholin, a professor of anatomy at the University of Copenhagen. ${ }^{1}$ Currently, about 30,000 medical journals are published each year. $^{2}$

The Indian Society of Critical Care Medicine came into existence on October 9, 1993, with a small gathering of 13 people in Mumbai, with the aim of, among others to publish scientific papers, journals, monographs for upgrading knowledge and skill about Critical Care Medicine among members and nonmembers. In furtherance of this goal, the Indian Journal of Critical Care Medicine was started in $1996 .{ }^{3}$ From being published sporadically in the beginning, it has now grown into a high-quality specialty open access journal with monthly publication, with theme based supplements. Apart from this, the journal publishes guidelines and position statements of the society in special supplements. It became indexed with PubMed in 2010. IJCCM gets over 1,500 submissions annually from all over the globe. With the aim of being environment friendly, the journal is now entirely published electronically for the past 4 years, except for the print copies that are being sent to the interested members, teaching institutes, and corporate members. In 2021, the journal completed 25 years of scientific publication in areas of critical care, emergency medicine, and acute care.

During the period of growth, the journal faced many trials and tribulations, common to such endeavors. ${ }^{4}$ The Indian Journal of Critical Care Medicine was lucky and correct in its timing of starting publication that it did not face the main problem, faced by any new journals - finding readership. There was, has been, and always will be a great number of avid readers wanting to know what is
${ }^{1}$ Division of Critical Care Medicine, Tata Memorial Hospital, Homi Bhabha National University, Mumbai, Maharashtra, India

${ }^{2}$ Intensive Care Unit, Medanta Hospital, Gurugram, Haryana, India

Corresponding Author: Atul P Kulkarni, Division of Critical Care Medicine, Tata Memorial Hospital, Homi Bhabha National University, Mumbai, Maharashtra, India, e-mail: kaivalyaak@yahoo.co.in

How to cite this article: Kulkarni AP, Govil D. Memores Acti Prudentes Future! Indian J Crit Care Med 2022;26(1):1.

Source of support: Nil

Conflict of interest: None

happening in the exciting field of critical care medicine in India and neighboring countries.

The Indian Journal of Critical Care Medicine will continue to showcase the research of Indian intensivists, alongside others, and go from strength to strength due to our predominantly young cadre of over 13,000 members of the Indian Society of Critical Care Medicine. We look forward to a bright future as we "Learn from yesterday. Live for today. Hope for tomorrow."

Memores acti prudentes future!-Mindful of what has been done, aware of what will be!

\section{References}

1. Available from: http://beckerexhibits.wustl.edu/rare/collections/ periodicals.html/ [Last accessed on December 20, 2021].

2. Available from: https://www.webmd.com/a-to-z-guides/medicaljournals/ [Last accessed on December 20, 2021].

3. Kulkarni AP, Zirpe KG, Dixit SB, Chaudhry D, Mehta Y, Mishra RC, et al. Development of critical care medicine in India. Indian J Crit Care Med 2020;56:188-196. DOI: 10.1016/j.jcrc.2019.11.017.

4. Trikha A. On starting a new medical journal: Problems, challenges, and remedies. Indian Anaesth Forum 2016;17(1):3-5. DOI: 10.4103/09730311.183576 .

() The Author(s). 2022 Open Access This article is distributed under the terms of the Creative Commons Attribution 4.0 International License (https://creativecommons. org/licenses/by-nc/4.0/), which permits unrestricted use, distribution, and non-commercial reproduction in any medium, provided you give appropriate credit to the original author(s) and the source, provide a link to the Creative Commons license, and indicate if changes were made. The Creative Commons Public Domain Dedication waiver (http://creativecommons.org/publicdomain/zero/1.0/) applies to the data made available in this article, unless otherwise stated. 